\title{
Allowance for Corporate Equity and Tax Aggressiveness: Do Family Firms Differ from Non-Family Firms?
}

\author{
Jonathan Bauweraerts \\ Warocque School of Economics and Management, Accounting and Management Department \\ 17 Place Warocqué, 7000 Mons, Belgium
}

Tel: 3265/37-32-76. E-mail: jonathan.bauweraerts@umons.ac.be

\begin{abstract}
Julien Vandernoot
Warocque School of Economics and Management, Public Finance and Tax Department

17 Place Warocqué, 7000 Mons, Belgium
\end{abstract}

Tel: 3265/37-32-69Ｅ-mail: julien.vandernoot@umons.ac.be

Received: Feb. 22, 2013 Accepted: April 2, 2013 Published: April 10, 2013

doi:10.5296/jmr.v5i3.3288～～URL: http://dx.doi.org/10.5296/jmr.v5i3.3288

\begin{abstract}
The purpose of this paper is to analyse the relationship between family ownership and tax aggressiveness in private companies by taking into account a regulatory framework including an "allowance for corporate equity" system. The results, obtained from a sample of 215 private Belgian firms, suggest a positive relationship between family involvement in business and tax aggressiveness. Moreover, the introduction of the notional interests system in 2006 induces a significant raise in the corrected equity, used as a specific tax aggressiveness indicator, without distinction between Belgian private family and non-family firms. The results indicate that the origins of the family firms' tax activism must still be analysed in depth.
\end{abstract}

Keywords: Tax aggressiveness, Family firms, Corporate tax, Allowance for Corporate Equity

JEL Classification: G30, G38, K34. 


\section{Introduction}

Taxes represent a comprehensive cost for each company and the temptation is high to engage in aggressive tax plans in order to maximise shareholder value and to have enough resource at disposal for investment projects. Nevertheless, non-financial costs may arise from tax aggressiveness so that the implementation of such practices leads to a new trade-off between tax savings and these costs. Non-fiscal costs vary according to the kind of organization. Family firms, whose objectives also integrate a socio-emotional dimension (Gomez-Mejia et al., 2007), are more concerned with their reputation and their image that can be eroded by a pronounced tax activism (Chen et al., 2010).

The purpose of this paper is to carry out a comparative analysis between private family and non-family firms regarding tax aggressiveness. Moreover the effects of changes in tax law (Laporta et al., 1999) as well as the financial crisis are taken into account. Indeed, the introduction of an allowance for corporate equity in 2006, called "notional interests" in Belgium, and the bad economic situation can affect tax practices. Hence, tax aggressiveness is investigated in an innovative way since our research is built on a comparison between private firms and tries to draw attention to the origins of aggressive tax practices by focusing on the effect of an allowance for corporate equity.

The analysis is based on a sample of 215 private family and non-family firms, that kind of organization being underinvestigated in the literature (Astrachan, 2010). Three models based on panel data collected for the period 2002-2010 are built up by using Generalized and Ordinary Least Squared methods. Firstly, we show whether family firms are more or less tax aggressive than non-family firms. Secondly, we try to see the effect of the introduction of an allowance for corporate equity as well as the financial crisis after subsampling for family and non-family firms. Finally, our last regression uses a specific tax aggressiveness indicator created by taking into account the calculation of the notional interests so that we can assess whether the new tax regulation has a causal effect on tax aggressiveness.

This paper is organised in several sections. Our first section is a literature review regarding the nexus between tax aggressiveness and family firms. Sections 2 to 4 describe the sampling process and the methodological aspects of our analysis. Finally, conclusions, limits and future developments are highlighted in a last section.

\section{Literature review}

Free cash-flow is significantly reduced by corporate tax. Aggressive tax practices are therefore full of meaning. Tax aggressiveness is defined by Frank et al. (2009) as downward management of taxable income through tax planning activities which can be legal or illegal or may lie in between. According to this definition, the extent a firm is involved in tax aggressive practices has to be decided by the management. In that regard, Dyreng et al. (2010) emphasize the role of the CEO regarding the fiscal choices made by the firms. That role devoted to management implies the existence of several mechanisms allowing the firms to minimize the tax burden. Since high-technical skills are needed to evade tax payment, decision makers (managers) have a sufficient discretionary space to conceal rent extraction 
vis-à-vis the other shareholders. Several examples of tax loopholes may be put into perspective such as transfer-pricing, corporate-owned life insurance, offshore intellectual property havens or cross-border dividend capture (Graham and Tucker, 2006).

Under Belgian tax law, some particularities of the legislation create opportunities to develop tax engineering characterized by high complexity. Bauweraerts and Vandernoot (Forthcoming) indicates: "As an example, in the current state of the Belgian tax law, dividends received by Belgian companies are deductible from their taxable profits as dividends received by up to 95\% at most of the gross amount of the dividends. Indeed, by meeting several conditions, dividends which are taxed abroad at a lower tax rate than in Belgium are subject to taxation for only 5\% of their gross amount. In that case, the tax burden born by the mother company can be considerably reduced. The use of this type of tax planning is a good example of tax-aggressive activities which are induced by local legislation."

In addition to this mechanism, an important provision has been introduced in 2006 in order to equalize the cost of equity and debt capital. That kind of allowance for corporate equity is called the notional interests and was created to replace the advantageous tax regime granted to the coordination centres since that regime has been judged illegal by the European Court of Justice in $2003^{1}$. The notional interests system find therefore two economic legitimations: maintaining employment in coordination centres and eradicating discrimination against risky capital (Valenduc, 2009). Besides, its implementation allows the firms having their headquarter in Belgium to benefit from the deduction of a fictitious interest calculated on the corrected equity at the long-term Belgian bonds' rate. Such an opportunity reduce the tax burden can have an impact on the tax aggressiveness in Belgian firms. That assumption is studied in our empirical analysis.

Local tax law has been shown to have an impact on tax aggressiveness since it creates plenty of opportunities for managers to reduce the tax burden. Furthermore, tax aggressiveness creates advantages and disadvantages that are different according to the firm or the shareholders' perspective. The main advantage of tax aggressiveness is tax savings which profit both the firm and the shareholders by increasing the firm cash-flow. Moreover, Chen et al. (2010) notice that managers whose compensation is directly or indirectly linked with the implementation of tax engineering are another gainers from tax planning.

Disadvantages arising from tax aggressiveness are the most harmful. In that regard, Chen et al. (2010) draw attention to the importance of both reputation and financial costs since tax reassessment erodes the firm's image in addition to affect directly its profits. Deslandes and Landry (2011) stress the increasing attention paid to the social responsibility and the detrimental consequences that tax evasion can cause to the firm. The separation between ownership and management induces another disadvantage. CEOs are assessed in function of their ability to create wealth for shareholders. Therefore, they have an impetus to engage in tax aggressiveness to minimize tax costs although it can cause damage on the firm's reputation. Moreover, agency costs can arise if the CEO takes advantage of tax aggressiveness to hide rent extraction activities such as perquisite consumption, excessive

\footnotetext{
${ }^{1}$ Official Journal of European Communities, 30 October 2003.
} 
salaries or earnings management (Steijvers and Niskanen, 2011). In cases where the shareholders are aware of these practices, a price discount on the firm's share can occur due to the influence of the market for corporate control (Lubatkin et al., 2005).

For family firms, an exacerbation of the advantages and disadvantages linked with tax aggressiveness appears. These organizations, which contribute in a comprehensive way to the economic fabric (Ifera, 2003; Duh et al., 2009), show some idiosyncrasies that can explain this assumption. Before digging deeper in our analysis, we have to give our definition of what we mean by family firms since no consensus is stated in the literature. By considering the current common standards (Anderson and Reeb, 2003; Villalonga and Amit, 2010; Colot 2010; Chen et al., 2010), we define a family firm as a firm where a family is either involved in the management or in the board or in the ownership as a majority shareholder.

By referring to the family firm's particularities, Chen et al. (2010) argue that as well advantages as disadvantages are more important in family firms than in non-family firms. Underlining that founder family members generally own more shares than CEO in non-family firms, Chen et al. (2010) demonstrate growing interest for family owners to get involved in rent extraction activities as their influence in the firm is important owing to their implication in ownership and management. Indeed, strong family involvement increases the probability of diverting resources and adopting opportunistic behaviours (Villalonga and Amit, 2006). Furthermore, in private firms, rent extraction activities and personal consumption by family managers/owners are more likely to occur since these behaviours are not sanctioned by a discount imposed by minority shareholders (Desai and Dharmapala, 2006). Lack of external discipline imposed by the market for corporate control increases the discretionary space of the managers since information asymmetry is higher in private firms than in public firms (Lubatkin et al., 2005).

Chen et al. (2010) also indicate that the potential risk of agency costs decreases in family firms. While Jensen and Meckling (1976) consider agency conflict to be reduced in family firms owing to an alignment of interests between family owner and manager, divergences of interests may occur between founding family or later generation owners (Eddleston and Kidwell, 2010). Moreover, family owners being characterized by wealth under-diversification (Gomez Mejia et al., 2007), they are more sensitive to the financial or civil sanctions they can suffer from tax aggressive practices. Besides, the temporal horizon of family managers is longer than this of non-family managers in other kind of organization (Lumpkin and Brigham, 2011). Consequently, they are more likely to be punished by belated administrative sanctions. In addition, family firms are more sensitive to the damage to their image since family owners/managers usually want to pass their company to their heirs in order to preserve family dynasty and perpetuate family values through the business (Casson, 1999; Steijvers and Niskanen, 2011).

The economic downturn of 2008 can have an impact on the behaviours of the firm regarding tax aggressiveness. Indeed, during an economic turmoil, family firms show better performance than non-family firms (Amit and Villalonga, 2006; Zhou, 2012; Bloch et al., 2012). As a result, their tax base is higher, what can induce aggressive tax practices. On the 
other hand, Lins et al. (2012) bring evidence from 40 countries that public family firms underperform non-family firms, reducing the incentive to take advantage of tax loopholes.

As it has been stated, define strong assumptions regarding the relationship between family involvement and tax aggressiveness is particularly hard. The next sections attempt to take a fresh look on the Belgian market of private firms by taking into account the family involvement, the financial crisis and the allowance for corporate equity as explaining variable of tax aggressiveness.

\section{Methodology}

\subsection{Target population}

Our sample is built in several steps by using the Belfirst financial database as well as the internet websites of each firm. Using that method allows us to obtain accurate information concerning ownership, board and management composition. Firstly, firms presenting an average number of permanent staff lower than 100 workers are eliminated so that they comply with the definition of a large company in Belgium. It was important in our analysis because small firms benefit from a higher notional interests deduction rate. Therefore, integrating them could create a bias. Secondly, each firm was considered as a family firm if it fulfilled at least one of the following criteria:

- family members owned at least 50\% of the firm's shares;

- management is mainly exerted by family members;

- board positions are mainly occupied by family members.

This multi-criteria definition is in accordance with the modern definition of a family firm (Anderson \& Reeb, 2003; Arregle et al, 2008; Colot, 2010; Chen et al., 2010; Villalonga and Amit, 2010). Moreover, it also takes into account mechanisms such as pyramidal structures that allow a family to keep control over a firm without owning the majority of its shares (Laporta et al, 1999; Gombers, 2010). 119 private family firms have been collected using these criteria.

In order to limit demographic bias such as size and sector's affiliation, non-family firms have been collected according to the following criteria:

- sector of activity: NACEBEL code (Belgian economic activities nomenclature, with 4 figures) identical to family firms;

- $\quad$ size: total assets cannot vary more than $20 \%$ compared to family firms.

Indeed, financial indicators are sensitive to economic activities and size (Ooghe and Van Wymeersch, 2006). Our method therefore reduces the volatility induced by these factors and makes our sample more homogeneous. 231 private firms are collected whose 16 are eliminated because of a lack in financial information in the Belfirst database. Our final sample is made up of 111 family firms and 104 non-family firms. 


\subsection{Models estimated}

Based on panel and cross-section data collected on the period 2002-2010, regressions are constructed by using Generalized Least Square (GLS) and Ordinary Least Square (OLS) methods. Our first model determinates if family involvement has an impact on tax aggressiveness and presents as follows:

$$
\begin{aligned}
\text { TaxAgg }_{i, t}=\alpha_{0}+ & \beta_{1} \text { Family }_{i}+\beta_{2} \text { Size }_{i, t}+\beta_{3} \text { Roa }_{i, t}+\beta_{4} \text { Leverage }_{i, t}+\beta_{5} P P E_{i, t}+ \\
& \beta_{6} \text { Intangible }_{i, t}+\sum_{s=7}^{S} \beta_{s} \text { sector }_{s}+\varepsilon_{i t}
\end{aligned}
$$

For our second model, we subsample between family and non-family firms in order to see the effects of the economic crisis as well as the introduction of an allowance for corporate equity on tax aggressiveness in family and non-family firms. The underlying idea is to see whether the evolution of the institutional and economic environment affects tax aggressiveness and therefore our results obtained in our first regression. Our model presents as follows:

$$
\begin{aligned}
\text { TaxAgg }_{i, t}= & \alpha_{0}+\beta_{1} \text { Notional }_{t}+\beta_{2} \text { Crisis }_{t}+\beta_{3} \text { Size }_{i, t}+\beta_{4} \text { Roa }_{i, t}+\beta_{5} \text { Leverage }_{i, t}+ \\
& \beta_{6} \text { PPE }_{i, t}+\beta_{7} \text { Intangible }_{i, t}+\sum_{s=8}^{S} \beta_{s} \text { sector }_{s}+\varepsilon_{i t}
\end{aligned}
$$

Finally, to improve the robustness of our survey, we test the last specification with an indicator of tax aggressiveness (corrected equity) specifically defined for the Belgian market. Our third model presents as follows:

$$
\begin{gathered}
\text { Corrected equity }_{i, t}=\alpha_{0}+\beta_{1} \text { Notional }_{t}+\beta_{2} \text { Crisis }_{t}+\beta_{3} \text { Size }_{i, t}+\beta_{4} \text { Roa }_{i, t}+\beta_{5} \text { Leverage }_{i, t}+ \\
\beta_{6} \text { PPE }_{i, t}+\beta_{7} \text { Intangible }_{i, t}+\sum_{s=8}^{S} \beta_{s} \text { sector }_{s}+\varepsilon_{i t}
\end{gathered}
$$

\subsection{Variables description}

Two indicators are used to assess the level of tax aggressiveness as a dependent variable. A first indicator is given by the amount of tax paid divided by the earnings before taxes. This indicator allows us to capture the effective tax expense of the firm (Dyreng et al., 2008; Deslandes and Landry, 2011). Moreover, to avoid timing and tax planning biases (Ayers et al., 2009) and to take into account the longer-term tax strategies of the firm (Deslandes and Landry, 2011), a mean of this indicator is calculated for each company. A second specific indicator is given by the corrected equity that is defined as follows: Equity - Re-evaluation reserves - Subsidies - Own shares - Other financial assets. We used this indicator because it is the base of calculation for the notional interests deduction, and therefore a good indicator of tax aggressiveness.

We incorporate several independent variables in our models. Family $y_{i}$ is a dummy variable with a value 1 if a firm is considered as a family firm according to our definition of the family firm, 0 otherwise. Notional ${ }_{t}$ is dummy variable with value 1 from the introduction of an allowance for corporate equity in 2006, 0 otherwise. Crisis ${ }_{t}$ is a dummy variable with value 1 from 2008 to 2010, 0 otherwise. We choose for 2008 as a starting point for the crisis since it is the year of Lehman Brother's bankruptcy, an event recognized as such in the literature (Lins et al., 2011). Other control variables are used in accordance with the common standards in the literature regarding tax aggressiveness (Frank et al., 2009; Chen et al., 2010). Size $_{i, t}$ is a control variable for size and is defined as the lagged natural logarithm of total asset. 
Roa $_{i, t}$ is a control variable related to profitability and is defined as Earnings before interests and taxes divided by total asset. Leverage $e_{i, t}$ is a control variable for the capital structure of the firm and is defined as the amount of debts divided by total asset. $P P E_{i, t}$ and Intangible $e_{i, t}$ are control variables taking into account the potential difference between accounting and tax situation. They are defined respectively as the amount of plants, properties and equipment divided by total asset and the amount of intangibles divided by total asset. Sector $_{i, t}$ is a dummy variable used to control for sector's affiliation.

\section{Results and interpretations}

Table 1. Descriptive statistics

The two last columns report the two-sided p-values for the difference between family and non-family firms in means and median, respectively. T-tests (Wilcoxon rank tests) are used to test the difference in means (medians).

\begin{tabular}{|c|c|c|c|c|c|c|}
\hline & \multicolumn{2}{|c|}{ Family firms } & \multicolumn{2}{|c|}{ Non-family firms } & \multicolumn{2}{|c|}{$\begin{array}{c}\text { P-value of the } \\
\text { differences }\end{array}$} \\
\hline & Mean & Median & Mean & Median & Mean & Median \\
\hline Total asset & 32972.860 & 20201.000 & 36602.530 & 22331.000 & 0.051 & 0.012 \\
\hline Tax Expense & 0.118 & 0.150 & 0.420 & 0.154 & 0.017 & 0.993 \\
\hline Age & 33.877 & 30.675 & 30.824 & 25.242 & 0.001 & 0.000 \\
\hline Staff & 244.735 & 152.000 & 224.194 & 171.000 & 0.052 & 0.085 \\
\hline Intangible & 0.008 & 0.000 & 0.016 & 0.000 & 0.019 & 0.999 \\
\hline PPE & 0.248 & 0.192 & 0.197 & 0.148 & 0.000 & 0.000 \\
\hline Leverage & 0.127 & 0.081 & 0.097 & 0.028 & 0.000 & 0.000 \\
\hline Corrected Equity & 0.341 & 0.266 & 0.301 & 0.255 & 0.023 & 0.021 \\
\hline ROA & 0.055 & 0.041 & 0.060 & 0.041 & 0.202 & 0.630 \\
\hline Sector's affiliation: & & Mean & Mean & & & \\
\hline Manufacturing & & 0.351 & 0.375 & & & \\
\hline Building & & 0.324 & 0.317 & & & \\
\hline Trade & & 0.171 & 0.163 & & & \\
\hline Transport & & 0.063 & 0.067 & & & \\
\hline Other services & & 0.090 & 0.077 & & & \\
\hline
\end{tabular}

Table 1 shows the homogeneity between family and non-family firms regarding their sector's affiliation. Referring to the p-values, significant differences appear between our other explaining variables. In average, family firms are older and present higher levels of permanent staff, PPE, leverage and corrected equity. However, total asset, tax expenses, intangibles as well as economic performance assessed by ROA are lower in family firms when comparing their means. Besides, the medians' analysis draws attention to tax expenses that appear to be more scattered in non-family than in family firms. 


\section{Macrothink}

Table 2. Pearson’s correlation matrix

\begin{tabular}{|c|c|c|c|c|c|c|c|c|c|c|}
\hline & TaxExpense & Family & Notional & Crisis & Size & ROA & Leverage & Intangible & PPE & Equity \\
\hline TaxExpense & 1.000 & & & & & & & & & \\
\hline Family & $\begin{array}{c}-0.054 * * \\
(0.017)\end{array}$ & 1.000 & & & & & & & & \\
\hline Notional & $\begin{array}{l}-0.002 \\
(0.927)\end{array}$ & $\begin{array}{c}0.000 \\
(1.000)\end{array}$ & 1.000 & & & & & & & \\
\hline Crisis & $\begin{array}{l}-0.010 \\
(0.672)\end{array}$ & $\begin{array}{c}0.000 \\
(1.000)\end{array}$ & $\begin{array}{c}0.633^{* * *} \\
(0.000)\end{array}$ & 1.000 & & & & & & \\
\hline Size & $\begin{array}{l}-0.037 \\
(0.105)\end{array}$ & $\begin{array}{c}-0.062 * * * \\
(0.006)\end{array}$ & $\begin{array}{c}0.167 * * * \\
(0.000)\end{array}$ & $\begin{array}{c}0.163 * * * \\
(0.000)\end{array}$ & 1.000 & & & & & \\
\hline Roa & $\begin{array}{l}-0.012 \\
(0.612)\end{array}$ & $\begin{array}{l}-0.029 \\
(0.202)\end{array}$ & $\begin{array}{c}0.029 \\
(0.201)\end{array}$ & $\begin{array}{l}-0.032 \\
(0.167)\end{array}$ & $\begin{array}{l}-0.013 \\
(0.565)\end{array}$ & 1.000 & & & & \\
\hline Leverage & $\begin{array}{l}-0.024 \\
(0.287)\end{array}$ & $\begin{array}{c}0.101^{* * *} \\
(0.000)\end{array}$ & $\begin{array}{c}0.016 \\
(0.490)\end{array}$ & $\begin{array}{l}-0.006 \\
(0.798)\end{array}$ & $\begin{array}{c}0.097 * * * \\
(0.000)\end{array}$ & $\begin{array}{c}-0.169 * * * \\
(0.000)\end{array}$ & 1.000 & & & \\
\hline Intangible & $\begin{array}{c}-0.078 * * * \\
(0.001)\end{array}$ & $\begin{array}{c}-0.053^{* *} \\
(0.019)\end{array}$ & $\begin{array}{l}-0.010 \\
(0.672)\end{array}$ & $\begin{array}{l}-0.009 \\
(0.685)\end{array}$ & $\begin{array}{l}0.043^{*} \\
(0.057)\end{array}$ & $\begin{array}{l}-0.002 \\
(0.923)\end{array}$ & $\begin{array}{c}0.137 * * * \\
(0.000)\end{array}$ & 1.000 & & \\
\hline PPE & $\begin{array}{c}-0.050 * * \\
(0.029)\end{array}$ & $\begin{array}{c}0.136 * * * \\
(0.000)\end{array}$ & $\begin{array}{c}0.036 \\
(0.113)\end{array}$ & $\begin{array}{l}-0.002 \\
(0.916)\end{array}$ & $\begin{array}{c}-0.145^{* * *} \\
(0.000)\end{array}$ & $\begin{array}{c}-0.063^{* * *} \\
(0.006)\end{array}$ & $\begin{array}{c}0.442 * * * \\
(0.000)\end{array}$ & $\begin{array}{c}-0.053 * * \\
(0.021)\end{array}$ & 1.000 & \\
\hline Equity & $\begin{array}{c}-0.084 * * * \\
(0.000)\end{array}$ & $\begin{array}{l}0.052 * * \\
(0.023)\end{array}$ & $\begin{array}{c}0.016 \\
(0.470)\end{array}$ & $\begin{array}{c}0.010 \\
(0.652)\end{array}$ & $\begin{array}{c}-0.013^{* *} \\
(0.581)\end{array}$ & $\begin{array}{c}0.200 * * * \\
(0.000)\end{array}$ & $\begin{array}{c}-0.161^{* * *} \\
(0.000)\end{array}$ & $\begin{array}{c}0.577^{* * *} \\
(0.000)\end{array}$ & $\begin{array}{c}0.028 \\
(0.224)\end{array}$ & 1.000 \\
\hline
\end{tabular}

$*, * *, * * *$, significant at the $10 \%, 5 \%$ and $1 \%$ threshold respectively. (two-tailed test).

Table 2 reveals relevant relationships in our problematic. A significant and negative relationship between family involvement and tax expenses is stated, corroborating the results in table 1. Furthermore, a positive and significant relationship is shown between family involvement and leverage. It is an unexpected result since private family firms are more risk averse and prefer self-financing than debt issuance (Gallo and Vilaseca, 1996; Colot and Croquet, 2007). A positive and significant relationship is also stated between the introduction of the notional interests mechanism and the size of the firms. That observation can be explained by a higher ease in large firms to engage in new tax practices reducing the tax burden. Finally, PPE is positively correlated with leverage while an opposite relationship is noticed between corrected equity and leverage, corroborating our expectations. 
Table 3. Tax agressiveness in family and non-family firms

\begin{tabular}{|c|c|c|c|}
\hline & & $\begin{array}{c}\text { Tax Expense } \\
\text { (GLS) }\end{array}$ & $\begin{array}{l}\text { Averaged Tax } \\
\text { Expense (OLS) }\end{array}$ \\
\hline \multirow{2}{*}{\multicolumn{2}{|c|}{ Constant }} & $1.836^{* *}$ & $0.899 * * *$ \\
\hline & & $(0.796)$ & $(0.200)$ \\
\hline \multirow{2}{*}{\multicolumn{2}{|c|}{ Family }} & $-0.331^{* *}$ & $-0.094 * * *$ \\
\hline & & $(0.141)$ & $(0.035)$ \\
\hline \multirow{2}{*}{\multicolumn{2}{|c|}{ Size }} & -0.102 & $-0.042 * *$ \\
\hline & & $(0.077)$ & $(0.019)$ \\
\hline \multirow{2}{*}{\multicolumn{2}{|c|}{ Roa }} & -0.292 & $-0.449 * *$ \\
\hline & & $(0.706)$ & $(0.182)$ \\
\hline \multirow{2}{*}{\multicolumn{2}{|c|}{ Leverage }} & 0.423 & $-0.392 * * *$ \\
\hline & & $(0.523)$ & $(0.136)$ \\
\hline \multirow{2}{*}{\multicolumn{2}{|c|}{ Intangible }} & $-3.019 * * *$ & 0.006 \\
\hline & & $(0.832)$ & $(0.219)$ \\
\hline \multirow{2}{*}{\multicolumn{2}{|c|}{ PPE }} & -0.525 & 0.118 \\
\hline & & $(0.445)$ & $(0.114)$ \\
\hline \multirow[t]{8}{*}{ Sectors: } & \multirow[t]{2}{*}{ Manufacturing } & -0.244 & -0.017 \\
\hline & & $(0.274)$ & $(0.067)$ \\
\hline & \multirow[t]{2}{*}{ Building } & 0.010 & -0.111 \\
\hline & & $(0.280)$ & $(0.069)$ \\
\hline & \multirow[t]{2}{*}{ Trade } & $-0.732 * *$ & -0.078 \\
\hline & & $(0.306)$ & $(0.075)$ \\
\hline & \multirow[t]{2}{*}{ Transport } & $-0.845 * *$ & $0.160 *$ \\
\hline & & $(0.375)$ & $(0.092)$ \\
\hline & R squared & 0.025 & 0.023 \\
\hline & F value & $43.100 * * *$ & $4.580 * * *$ \\
\hline & $\mathrm{N}$ & 1935 & 1935 \\
\hline
\end{tabular}

$*, * *, * * *$, significant at the $10 \%, 5 \%$ and $1 \%$ threshold respectively. (two-tailed test).

Standard errors are reported in parentheses.

Regressions in table 3 indicate a significant and negative relationship between family involvement and yearly or averaged tax expenses. These results suggest therefore a higher level of tax aggressiveness in private family firms and are contradictory to these obtained in public firms (Chen et al., 2010). Indeed, literature generally admits a higher tax burden in public family firms, that kind of company putting a major emphasis on the development of a positive image that contributes to the improvement of the relationships with the stakeholders 
(Miller and Le Breton-Miller, 2005). However, in private firms, the pressure exerted by stakeholders can be reduced. The potential price discount imposed by minority shareholders (Steijvers and Niskanen, 2011) is mitigated since the discipline induced by the market for corporate control is weaker in private firms owing to a more important information asymmetry in that kind of organization (Lubatkin and al., 2005).

Table 4. Notional interests and crisis effects on tax aggresiveness

\begin{tabular}{|c|c|c|c|c|c|}
\hline & & \multicolumn{2}{|c|}{ Family firms } & \multicolumn{2}{|c|}{ Non-family firms } \\
\hline & & $\begin{array}{c}\text { Tax Expense } \\
\text { (GLS) }\end{array}$ & $\begin{array}{c}\text { Averaged Tax } \\
\text { Expense (OLS) }\end{array}$ & $\begin{array}{c}\text { Tax Expense } \\
\text { (GLS) }\end{array}$ & $\begin{array}{l}\text { Averaged Tax } \\
\text { Expense (OLS) }\end{array}$ \\
\hline & Constant & 1.469 & $0.598 * *$ & 1.922 & $1.017 * * *$ \\
\hline & & $(0.986)$ & $(0.298)$ & (1.300) & $(0.264)$ \\
\hline & Notional & 0.227 & 0.008 & -0.128 & 0.025 \\
\hline & & $(0.204)$ & $(0.068)$ & $(0.254)$ & $(0.056)$ \\
\hline & Crisis & -0.106 & -0.005 & -0.038 & -0.005 \\
\hline & & $(0.216)$ & $(0.072)$ & $(0.264)$ & $(0.058)$ \\
\hline & Size & -0.103 & -0.013 & -0.110 & $-0.064 * *$ \\
\hline & & $(0.101)$ & $(0.030)$ & $(0.126)$ & $(0.025)$ \\
\hline & ROA & 0.864 & -0.202 & -1.161 & $-0.701 * * *$ \\
\hline & & (1.026) & $(0.321)$ & (0.989) & $(0.205)$ \\
\hline & Leverage & 0.011 & -0.324 & 0.270 & $-0.546^{* * *}$ \\
\hline & & (0.673) & $(0.210)$ & $(0.842)$ & $(0.177)$ \\
\hline & PPE & -1.036 & -0.079 & 0.537 & $0.422 * * *$ \\
\hline & & $(0.544)$ & $(0.167)$ & $(0.743)$ & $(0.153)$ \\
\hline & Intangible & $-4.777 * * *$ & 0.078 & -0.050 & 0.067 \\
\hline & & $(0.994)$ & $(0.326)$ & (1.464) & $(0.299)$ \\
\hline Sectors: & Manufacturing & 0.016 & -0.135 & -0.542 & 0.107 \\
\hline & & $(0.347)$ & (0.103) & $(0.430)$ & $(0.086)$ \\
\hline & Building & -0.030 & -0.126 & 0.044 & -0.092 \\
\hline & & $(0.357)$ & $(0.106)$ & $(0.438)$ & $(0.087)$ \\
\hline & Trade & $-0.676^{*}$ & -0.078 & -0.770 & -0.095 \\
\hline & & $(0.391)$ & $(0.116)$ & $(0.477)$ & $(0.095)$ \\
\hline & Transport & $-0.809 *$ & -0.013 & -0.902 & $0.339 * * *$ \\
\hline & & $(0.481)$ & $(0.143)$ & $(0.583)$ & $(0.116)$ \\
\hline & R Squared & 0.051 & 0.007 & 0.018 & 0.081 \\
\hline & F Value & $48.220 * * *$ & 0.590 & $14.500 * * *$ & $7.390 * *$ \\
\hline & $\mathrm{N}$ & 999 & 999 & 936 & 936 \\
\hline
\end{tabular}

$*$, **, ***, significant at the $10 \%, 5 \%$ and $1 \%$ threshold respectively. (two-tailed test).

Standard errors are reported in parentheses. 
Table 4 integrates contextual factors, such as the crisis and the introduction of an allowance for corporate equity, to measure their influence on the tax policy led by private family and non-family firms in Belgium. According to our results, we can conclude on a significant effect of these two elements on the tax aggressiveness indicators used in table 3. Nevertheless, a trend can be noticed since 3 parameters out of 4 show a positive but insignificant relationship between the introduction of the notional interests mechanism and tax aggressiveness. In order to investigate deeper the effect of the introduction of an allowance for corporate equity on the tax policy of the firms, corrected equity is used to run our regressions in table 5 . We notice that the effect of the notional interests is more pronounced in non-family than in family firms, estimated parameters showing positive and significant values of 0.037 for non-family firms and 0.027 for family firms. That small difference between family and non-family firms indicates that the reasons of higher tax aggressiveness in family firms cannot be found in an aggressive notional interests policy in these organizations. However, the introduction of the notional interests has no significant influence on the averaged indicators. That observation and the positive relationship between the notional interests and the yearly indicator suggest that corrected equity increases at the end of the observation period. In addition, we also notice a positive and significant relationship between corrected equity and crisis in non-family firms. 
Table 5. Notional interests and crisis effects on corrected equity

\begin{tabular}{|c|c|c|c|c|c|}
\hline & & \multicolumn{2}{|c|}{ Family firms } & \multicolumn{2}{|c|}{ Non-family firms } \\
\hline & & $\begin{array}{l}\text { Corrected Equity } \\
\text { (GLS) }\end{array}$ & $\begin{array}{c}\text { Averaged Corrected } \\
\text { Equity (OLS) }\end{array}$ & $\begin{array}{c}\text { Corrected } \\
\text { Equity (GLS) }\end{array}$ & $\begin{array}{c}\text { Averaged } \\
\text { Corrected Equity } \\
\text { (OLS) }\end{array}$ \\
\hline & Constant & $\begin{array}{c}0.498 * * * \\
(0.097)\end{array}$ & $\begin{array}{c}0.029 \\
(0.079)\end{array}$ & $\begin{array}{c}0.758 * * * \\
(0.107)\end{array}$ & $\begin{array}{c}0.047 \\
(0.065)\end{array}$ \\
\hline & Notional & $\begin{array}{c}0.027 * * * \\
(0.009)\end{array}$ & $\begin{array}{l}-0.009 \\
(0.018)\end{array}$ & $\begin{array}{c}0.037 * * * \\
(0.009)\end{array}$ & $\begin{array}{l}-0.010 \\
(0.014)\end{array}$ \\
\hline & Crisis & $\begin{array}{c}0.004 \\
(0.010)\end{array}$ & $\begin{array}{c}0.007 \\
(0.019)\end{array}$ & $\begin{array}{c}0.029 * * * \\
(0.010)\end{array}$ & $\begin{array}{c}0.003 \\
(0.014)\end{array}$ \\
\hline & Size & $\begin{array}{c}-0.035^{* * *} \\
(0.009)\end{array}$ & $\begin{array}{c}0.020 * * * \\
(0.008)\end{array}$ & $\begin{array}{c}-0.056 * * * \\
(0.009)\end{array}$ & $\begin{array}{c}0.020 * * * \\
(0.006)\end{array}$ \\
\hline & ROA & $\begin{array}{c}0.535 * * * \\
(0.063)\end{array}$ & $\begin{array}{c}0.850 * * * \\
(0.085)\end{array}$ & $\begin{array}{c}0.400 * * * \\
(0.054)\end{array}$ & $\begin{array}{c}0.327 * * * \\
(0.051)\end{array}$ \\
\hline & Leverage & $\begin{array}{c}-0.270 * * * \\
(0.041)\end{array}$ & $\begin{array}{c}-0.329 * * * \\
(0.056)\end{array}$ & $\begin{array}{c}-0.216 * * * \\
(0.041)\end{array}$ & $\begin{array}{c}-0.327 * * * \\
(0.044)\end{array}$ \\
\hline & PPE & $\begin{array}{c}0.253^{* * *} \\
(0.038)\end{array}$ & $\begin{array}{c}0.145^{* * * *} \\
(0.044)\end{array}$ & $\begin{array}{l}-0.025 \\
(0.044)\end{array}$ & $\begin{array}{c}0.077 * * \\
(0.038)\end{array}$ \\
\hline & Intangible & $\begin{array}{c}5.395^{* * *} \\
(0.047)\end{array}$ & $\begin{array}{c}0.570 * * * \\
(0.087)\end{array}$ & $\begin{array}{c}0.037 \\
(0.104)\end{array}$ & $\begin{array}{c}0.053 \\
(0.074)\end{array}$ \\
\hline Sectors: & Manufacturing & $\begin{array}{l}0.122 * * \\
(0.062)\end{array}$ & $\begin{array}{c}0.099 * * * \\
(0.027)\end{array}$ & $\begin{array}{c}0.169 * * * \\
(0.063)\end{array}$ & $\begin{array}{c}0.124 * * * \\
(0.021)\end{array}$ \\
\hline & Building & $\begin{array}{c}0.065 \\
(0.062)\end{array}$ & $\begin{array}{c}0.029 \\
(0.028)\end{array}$ & $\begin{array}{l}-0.025 \\
(0.064)\end{array}$ & $\begin{array}{l}-0.030 \\
(0.022)\end{array}$ \\
\hline & Trade & $\begin{array}{c}0.096 \\
(0.068)\end{array}$ & $\begin{array}{c}0.141 * * * \\
(0.031)\end{array}$ & $\begin{array}{l}0.121^{*} \\
(0.070)\end{array}$ & $\begin{array}{c}0.078 * * * \\
(0.024)\end{array}$ \\
\hline & Transport & $\begin{array}{l}-0.088 \\
(0.085) \\
\end{array}$ & $\begin{array}{r}-0.034 \\
(0.038) \\
\end{array}$ & $\begin{array}{c}0.034 \\
(0.085) \\
\end{array}$ & $\begin{array}{c}0.078^{* * *} \\
(0.029) \\
\end{array}$ \\
\hline & $\begin{array}{l}\text { R Squared } \\
\text { F Value } \\
\mathrm{N}\end{array}$ & $\begin{array}{c}0.809 \\
14129.840^{* * *} \\
999\end{array}$ & $\begin{array}{c}0.241 \\
28.520 * * * \\
999\end{array}$ & $\begin{array}{c}0.189 \\
226.160^{* * *} \\
936\end{array}$ & $\begin{array}{c}0.248 \\
27.690 * * * \\
936\end{array}$ \\
\hline
\end{tabular}

$*, * *, * * *$, significant at the $10 \%, 5 \%$ and $1 \%$ threshold respectively. (two-tailed test).

Standard errors are reported in parentheses.

\section{Conclusion}

By positioning in the literature related to tax aggressiveness, our paper confirms the necessity to take into account the ownership structure of a firm as an explaining factor of tax aggressive practices. Our results show evidence that family involvement has a significant effect on tax aggressiveness measured by several indicators (Deslandes and Landry, 2011). Besides, by focusing on private firms, our research contributes to the literature in that way since previous 
work only focuses on public firms (Chen et al., 2010). Moreover, our results show the importance to take into account the listing of the firms, our results being contradictory to these obtain in public firms. While family firms perceive reputation as an indivisible element of their succession process (Miller et Le Breton-Miller, 2005; Zellweger et al., 2011), our statement establishes that immediate consumptions can also be considered in family firms because these organizations can be defined as an homogeneous group of people wanting to divert resource (Villalonga and Amit, 2006). That property can be more visible in private firms since information asymmetry is higher and induces a larger discretionary space, the market for corporate control lacking of disciplining these companies (Lubatkin et al, 2005).

Furthermore, our research also takes into account the evolutional context of tax law since it analyses the effect of the introduction of an allowance for corporate equity that triggers off a large debate in European instances (Valenduc, 2009). That approach also contributes to the literature on that point since the particularities of law have to be studied in order to catch the contextual framework of our research (Laporta et al., 1999). After subsampling for family and non-family firms, our results suggest that the introduction of the notional interests has a positive influence on corrected equity that has been defined as a specific indicator of tax aggressiveness. However, as no divergence can be stated between family and non-family firms, the origins of a higher level of tax aggressiveness in family firms has to be found in other tax loopholes on the Belgian market.

Our paper presents several limitations and opportunities for future developments. Firstly, the methodology used in that research has to be extended to a larger sample of private family firms in order that our results can be generally applied. Besides, our analysis regarding the effect of the notional interests on tax aggressiveness in private family firms can be experienced on Belgian public firms since this subject has not yet been investigated in that kind of companies. Moreover, since no difference appears between family and non-family firms regarding the effect of an allowance for corporate equity on tax aggressiveness, further investigation on the Belgian market may focus on the effect of other tax loopholes in order to explain the higher level of tax aggressiveness in private family firms.

A second limitation concerns the one-dimensional aspect of our definition of family involvement. Indeed, we don't distinguish between family involvement in ownership and management. That element could modify the relationship with the firms' performance (Block et al., 2011), and indirectly the tax policy of the firms. Taking it into account can be relevant since the ubiquity of family firms would be analysed according to their governance structure.

A third limitation is related to the statistical method used in our research. In that regard, Block et al., 2011) as well as Mazzi (2011) indicate that an interesting way to approach the effect of family involvement on firm's performance is based on a Bayesian approach. Such a method is transposable to tax aggressiveness and improves the accuracy concerning the level of acceptation of the null hypotheses. Furthermore, using a Bayesian approach could also mitigate a bias in the literature since statistical significance lower than $5 \%$ is frequently rejected (Block et al., 2011). 


\section{References}

Anderson, R., \& Reeb, D. (2003). Founding family ownership and firm performance: evidence from the S\&P 500. The Journal of Finance, 58(3), 1301-1327. http://dx.doi.org/10.1111/1540-6261.00567

Arregle, J. L., Sirmon, D. G., Hitt, M. A., \& Webb, J. W. (2008). The Role of Family Influence in Firms' Strategic Responses to Threat of Imitation. Entrepreneurship Theory and Practice, 32(6), 979-998. http://dx.doi.org/10.1111/j.1540-6520.2008.00267.x

Astrachan, J.H. (2010). Strategy in family business: Toward a multidimensional research agenda. Journal of Family Business Strategy, 1(1), 6-14. http://dx.doi.org/10.1016/j.jfbs.2010.02.001

Ayers, B., Jiang, X., \& Laplante, S. (2009). Taxable income as a performance measure: the effects of tax planning and earnings quality. Contemporary accounting research, 26(1), 15-54. http://dx.doi.org/10.1506/car.26.1.1

Bauweraerts, J., \& Vandernoot, J. (forthcoming). Are family firms more tax aggressive than non-family firms: Empirical evidence from Belgium. International Journal of Management.

Bloch, A., Kachaner, N., \& Mignon, S. (2012). La stratégie du propriétaire: Enquête sur la résilience des entreprises familiales face à la crise. Edition Pearson, Orléans, 188 pages.

Block, H.B., Jaskiewicz, P., \& Miller, D. (2011). Ownership versus management effects on performance in family and founder companies: A Bayesian reconciliation. Journal of Family Business Strategy, 2(4), 232-245. http://dx.doi.org/10.1016/j.jfbs.2011.10.001

Casson, M. (1999). The economics of the family firm. Scandinavian Economic History Review, 47(1), 10-23. http://dx.doi.org/10.1080/03585522.1999.10419802

Chen, S., Chen, X., Cheng, Q., and Shevlin, T. (2010). Are family firms more tax aggressive than non-family firms?. Journal of Financial Economics, 95, 41-61, http://dx.doi.org/10.1016/j.jfineco.2009.02.003

Colot, O. (2010). La performance de la Transmission des entreprises familiales, Editions Universitaires Européennes : Sarrebruck.

Colot, O., \& Croquet., M. (2007). Les déterminants de la structure financière des entreprises belges. Reflets et Perspectives de la vie économique, 46(2), 177-198.

Desai, M., \& Dharmapala, D. (2006). Corporate tax avoidance and high-powered incentives. Journal of Financial Economics, 79, 145-179. http://dx.doi.org/10.1016/j.jfineco.2005.02.002

Deslandes, M., \& Landry, S. (2011). «Risque d'atteinte à la réputation, composition du conseil d'administration et agressivité fiscale. La Revue Française de Gouvernance d'Entreprise, 9, 23-43.

Duh, M., Tominc, P., \& Rebernik, M. (2009). The Importance of Family Enterprises in Transition Economies: Is It Overestimated?. Eastern European Economics, 47(6), 22-42. 
http://dx.doi.org/10.2753/EEE0012-8775470602

Dyreng, S., Hanlon, M., \& Maydew E. (2010). The effects of executives on corporate tax avoidance. The Accounting Review, 85(4), 1163-1189. http://dx.doi.org/10.2308/accr.2010.85.4.1163

Eddleston, K.A., \& Kidwell, R.E. (2010). Parent-Child Relationships: Planting the Seeds of Deviant Behavior in the Family Firm. Entrepreneurship Theory and Practice, 36(2), 369-386. http://dx.doi.org/10.1111/j.1540-6520.2010.00403.x

Frank, M., Lynch, I., \& Rego, S. (2009). Tax reporting aggressiveness and its relation to aggressive financial reporting. The Accounting Review, 84, 467-496. http://dx.doi.org/10.2308/accr.2009.84.2.467

Gallo, M.A., \& Vilaseca, A. (1996). Finance in Family Business. Family Business Review, 9(4), 387-401. http://dx.doi.org/10.1111/j.1741-6248.1996.00387.x

Gombers, P.A., Ishii, J., \& Metrick, A. (2010). Extreme Governance: An analysis of dual-class firms in the United States.The Review of Financial Studies, 23(3), 1051-1088. http://dx.doi.org/10.1093/rfs/hhp024

Gomez-Mejia, L.R., Haynes, K.T., Nunez-Nickel, M., Jacobson, K.J.L., \& Moyano-Fuentes, J. (2007). Socioemotional wealth and business risk in family-controlled firms: Evidence from Spanish olive oil mills. Administrative Science Quarterly, 52(1), 106-137.

Graham, J., \& Tucker, A. (2006). Tax Shelters and corporate debt policy. Journal of Financial Economics, 81, 563-594. http://dx.doi.org/10.1016/j.jfineco.2005.09.002

Ifera. (2003). Family business dominate”, Family Business Review, 16(4), 235-239.

Jensen, M.C., \& Meckling W.H. (1976). Theory of the Firm: Managerial Behavior, Agency Costs and Ownership Structure. Journal of Financial Economics, 3(4), 305-360. http://dx.doi.org/10.1016/0304-405X(76)90026-X

Laporta, R., Lopez-De-Silanes, R., \& Shleifer, A. Corporate ownership around the world. The Journal of Finance, 54(2), 471-517. http://dx.doi.org/10.1111/0022-1082.00115

Lubatkin, M., Schulze, W., Ling, Y., \& Dino R. (2005). The effects of parental altruism on the governance of family-managed firms. Journal of Organizational Behavior, 26, 313-330. http://dx.doi.org/10.1002/job.307

Lumpkin, G.T., \& Brigham, K.H. Long-Term Orientation and Intertemporal Choice in Family Firms. Entrepreneurship Theory and Practice, 35(6), 1149-1169. http://dx.doi.org/10.1111/j.1540-6520.2011.00495.x

Mazzi, C. (2011). Family business and financial performance: current state of knowledge and future research challenges. Journal of Family Business Strategy, 2(3), 166-181. http://dx.doi.org/10.1016/j.jfbs.2011.07.001

Miller, D., \& Le Breton-Miller, I. (2005). Managing for the Long Run, Harvard Business 


\section{Macrothink}

Journal of Management Research

ISSN 1941-899X

2013, Vol. 5, No. 3

School Press: Boston, MA, 310 pages.

Ooghe, H., \& Van Wymeersch, C. (2006). Traité d'analyse financière, Intersentia - Artémis, Anvers.

Steijvers, T., \& Niskanen, M. (2011). Tax Aggressive Behaviour in Private Family Firms -the effect of the CEO and board of directors. Proceedings of the 7th European Conference on Management, Leadership and Governance. 2011, pp.379-386.

Villalonga, B., \& Amit, R. (2006). How do family ownership, control and management affect firm value?. Journal of Financial Economics, 80(2), 385-417. http://dx.doi.org/10.1016/j.jfineco.2004.12.005

Villalonga, B., \& Amit, R. (2010). Family Control of firms and industries. Financial Management, 39(3), 863-904. http://dx.doi.org/10.1111/j.1755-053X.2010.01098.x

Zellweger, T.M., Nason, R.S., Nordqvist, M., \& Brush, C.G. (2011). Why do family firms strive for nonfinancial goals? An organizational identity perspective. Entrepreneurship Theory and Practice. http://dx.doi.org/10.1111/j.1540-6520.2011.00466.x 